\title{
PNNL Coal Gasifier Transportation Logistics
}

DJ Reid

AD Guzman

April 2011

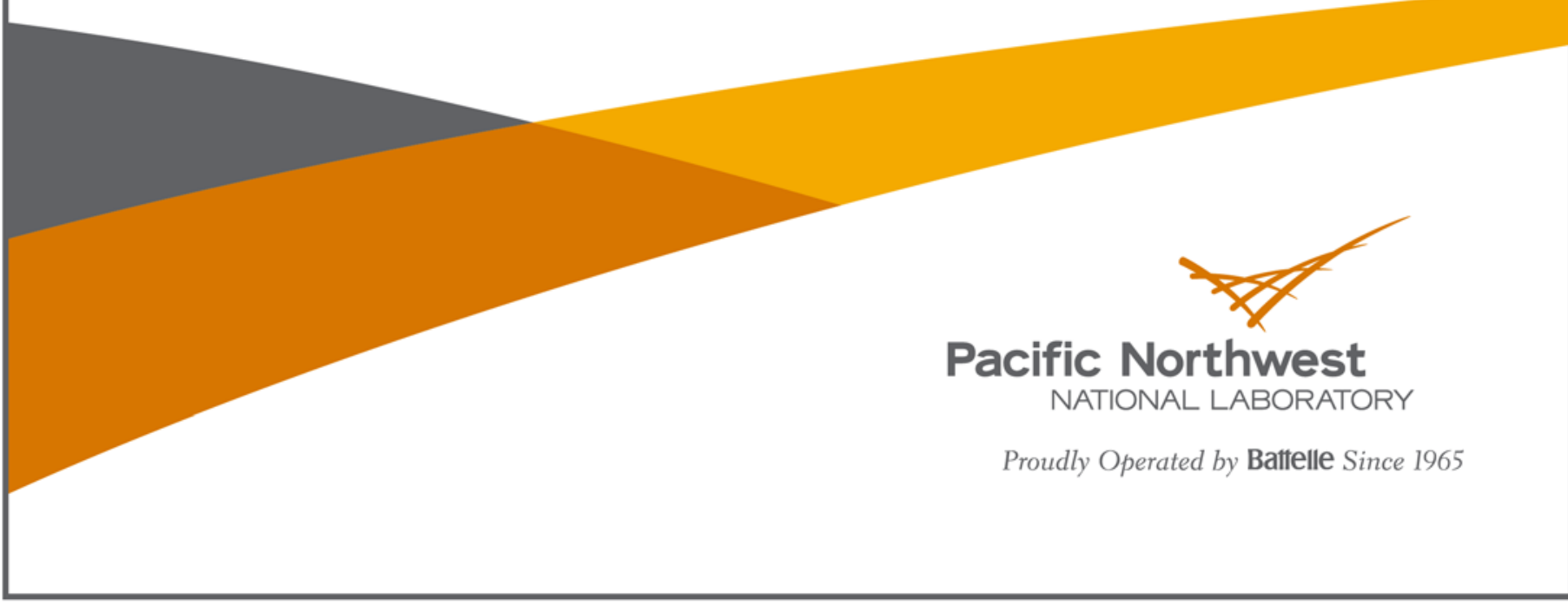




\title{
DISCLAIMER
}

This report was prepared as an account of work sponsored by an agency of the United States Government. Neither the United States Government nor any agency thereof, nor Battelle Memorial Institute, nor any of their employees, makes any warranty, express or implied, or assumes any legal liability or responsibility for the accuracy, completeness, or usefulness of any information, apparatus, product, or process disclosed, or represents that its use would not infringe privately owned rights. Reference herein to any specific commercial product, process, or service by trade name, trademark, manufacturer, or otherwise does not necessarily constitute or imply its endorsement, recommendation, or favoring by the United States Government or any agency thereof, or Battelle Memorial Institute. The views and opinions of authors expressed herein do not necessarily state or reflect those of the United States Government or any agency thereof.

\author{
PACIFIC NORTHWEST NATIONAL LABORATORY \\ operated by \\ BATTELLE \\ for the \\ UNITED STATES DEPARTMENT OF ENERGY \\ under Contract DE-AC05-76RL01830
}

Printed in the United States of America
Available to DOE and DOE contractors from the Office of Scientific and Technical Information,
P.O. Box 62, Oak Ridge, TN 37831-0062;
ph: (865) 576-8401
fax: (865) 576-5728
email: reports@adonis.osti.gov
Available to the public from the National Technical Information Service
5301 Shawnee Rd., Alexandria, VA 22312 ph: (800) 553-NTIS (6847)
email: orders@ntis.gov <http://www.ntis.gov/about/form.aspx>
Online ordering: http://www.ntis.gov




\title{
PNNL Coal Gasifier Transportation Logistics
}

\author{
DJ Reid \\ AD Guzman
}

April 2011

Prepared for

the U.S. Department of Energy

under Contract DE-AC05-76RL01830

Pacific Northwest National Laboratory

Richland, Washington 99352 



\section{Summary}

This report provides Pacific Northwest National laboratory (PNNL) craftspeople with the necessary information and suggested configurations to transport PNNL's coal gasifier from its current location at the InEnTec facility in Richland, Washington, to PNNL's Laboratory Support Warehouse (LSW) for short-term storage. A method of securing the gasifier equipment is provided that complies with the tiedown requirements of the Federal Motor Carrier Safety Administration's Cargo Securement Rules. 



\section{Acronyms and Abbreviations}

$\begin{array}{ll}\mathrm{ft} & \text { foot(feet) } \\ \mathrm{in} . & \text { inch(es) } \\ \mathrm{lb} & \text { pound(s) } \\ \mathrm{LSW} & \text { Laboratory Support Warehouse } \\ \text { POC } & \text { point of contact }\end{array}$





\section{Contents}

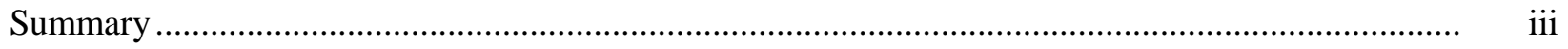

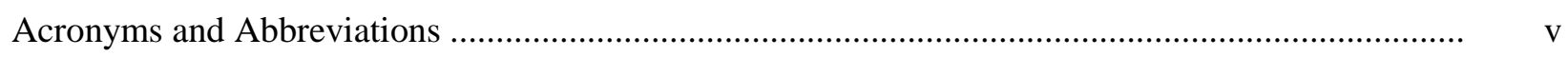

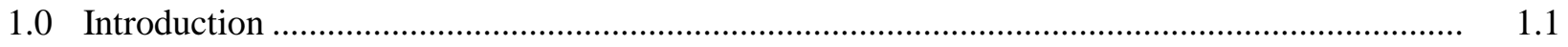

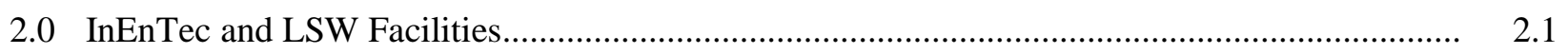

3.0 Assumptions and Requirements ..........................................................................

3.1 Tolerance Requirements............................................................................................ 3.1

3.2 Tie-Down Description and Equipment........................................................................... 3.2

4.0 A Proposed Tie-Down Configuration...........................................................................

4.1 Layout and Coordinate System …................................................................................... 4.1

4.2 Tie-Down Calculations …........................................................................................ 4.2

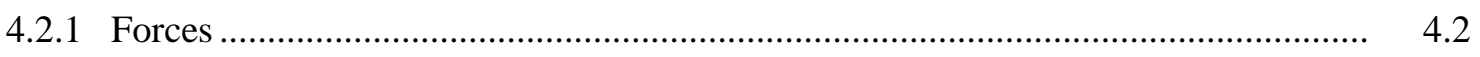

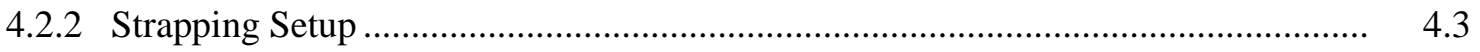

4.2.3 Lateral Restraint Calculations ........................................................................... 4.4

4.2.4 Vertical Restraint Calculations.................................................................... 4.4

4.2.5 Forward Restraint Calculations ................................................................................ 4.5

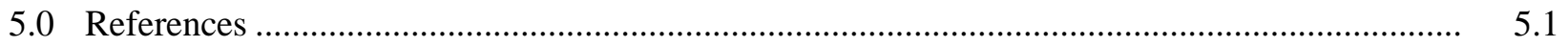

Appendix A - Drawings and Figures ............................................................................ A.1 


\section{Figures}

4.1 Tie-Down Example for the Gasifier Bosch Stand .....................................................................

4.2 Example of the Tie-Down Configuration for Spool Pieces ...................................................... 4.2

4.3 Angle Calculation Definition ................................................................................................. 


\subsection{Introduction}

One of Pacific Northwest National Laboratory’s (PNNL’s) Laboratory Directed Research and Development projects has involved a coal gasifier that was built and operated at the InEnTec facility (InEnTec LLC, 2011) in Richland, Washington. The gasifier is no longer being operated, so it is time to relocate the equipment in a PNNL storage facility. The fully assembled gasifier is too tall and heavy to move easily in its upright position. The InEnTec staff disassembled the three heavy spool pieces from the frame to allow for more modular transport. The frame will be laid down to prevent any over height transportation issues. All of the equipment will be transported to PNNL's LSW for short-term storage. PNNL craftspeople (Crafts) are required to place the Bosch frame upright in a standing position inside the LSW.

The ensuing sections briefly describe the source and destination facilities; the assumptions and requirements related to equipment handling, securement, and conveyance; and a proposed tie-down configuration. Appendix A contains related photos and equipment drawings. 



\subsection{InEnTec and LSW Facilities}

The gasifier frame, three palletized spool pieces, two empty palletized spool pieces, a palletized coal auger and miscellaneous hardware, and a palletized boiler reside in the warehouse at the InEnTec facility and will be transported to PNNL's LSW located north of Horn Rapids Road and PNNL's north campus facilities (see Figure A.1 in Appendix A). Figure A.2 shows the exterior of the InEnTec facility. Figure A.3 shows the laydown yard where the components will be loaded onto a trailer. The ground is moderately flat and consists of a gravel/asphalt mix. The entryway to the north campus LSW consists of gravel. Figure A.4 shows the open dimensions of the LSW doors. Figure A.5 shows the entryway transition "step" that may provide a challenge for unloading the components and transporting them into the LSW. Figure A.6 shows the interior of the LSW. 



\subsection{Assumptions and Requirements}

The specific tie-down methodology and conveyance used for transportation of the equipment is up to the discretion of Crafts. The transportation route and time of day will also be Crafts' responsibility. Coordination for pick-up times shall be arranged with the PNNL point of contact (POC) to ensure InEnTec staff availability. PNNL Crafts shall provide the proposed shipping date to PNNL POC by April 20 for labor and planning purposes.

The following assumptions are applicable to lifting and tying down the PNNL gasifier when preparing it for transportation to the LSW (see Figures A.7 to A.11):

- InEnTec staff will be responsible for moving the equipment out of their facility and loading it onto the PNNL transportation vehicles.

- The move involves the gasifier Bosch frame and six wooden pallets.

- The top spool piece on the pallet is assumed to weigh 1,800 lb at most.

- The Bosch stand with spools removed is assumed to weigh 1,750 lb at most.

- Two pallets, each with one spool piece, are assumed to weigh 1,500 lb at most per pallet. (Figure A.7)

- Two additional spool pieces on one pallet is assumed to weigh 1,500 lb at most (Figure A.9).

- Miscellaneous hardware (hopper, auger, etc.) on a pallet is assumed to weigh 1,500 lb at most.

- The boiler (Figure A.11) on a pallet is assumed to weigh 1,500 lb at most.

- The attachment points on the trailer or conveyance are assumed to withstand imposed tie-down loads.

- An 8-ft-wide lowboy trailer or equivalent meeting tie-down equivalency criteria is acceptable for transport.

- The Bosch stand must be oriented as shown in Figure 4.1.

- 4x4 lumber may be used to shim up the Bosch stand to level its position on the trailer.

- Metal banding will be used to secure the spool pieces onto their associated pallet.

- A rubber mat will be placed under loaded pallets. All calculations were made given this assumption.

\subsection{Tolerance Requirements}

Placement of the equipment on the conveyance is critical for centering the load. The following requirements apply:

- The gasifier Bosch stand will be centered laterally on the trailer with a tolerance of $+/-2$ in.

- The spool pieces and pallets will be centered laterally with a tolerance of $+/-2$ in.

- Crafts shall provide a tie-down configuration for the remaining components. 


\subsection{Tie-Down Description and Equipment}

The required hardware for the proposed tie down is as follows:

- Multiple chains or straps with a working load limit of 4,000 lb or greater.

- Rubber friction mats required between pallets and conveyance deck. 


\subsection{A Proposed Tie-Down Configuration}

This section presents the layout and coordinate system and tie-down calculations for a proposed tiedown configuration for the gasifier components, as an example.

\subsection{Layout and Coordinate System}

Figure 4.1 and Figure 4.2 below have three reference axes for clarification when referring to the tiedown configuration.

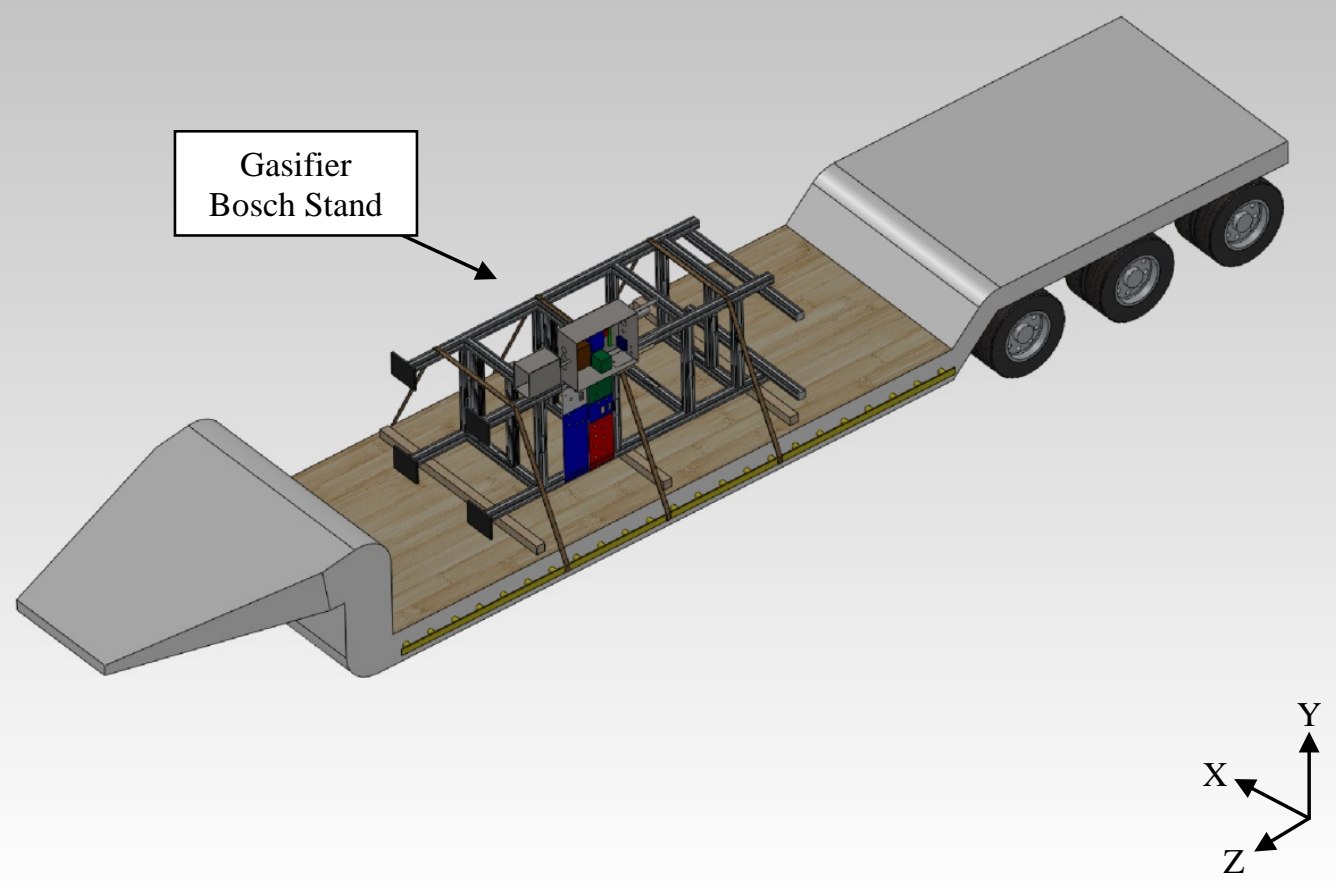

X: Lateral Y: Vertical Z: Forward/Aft

Figure 4.1. Tie-Down Example for the Gasifier Bosch Stand 


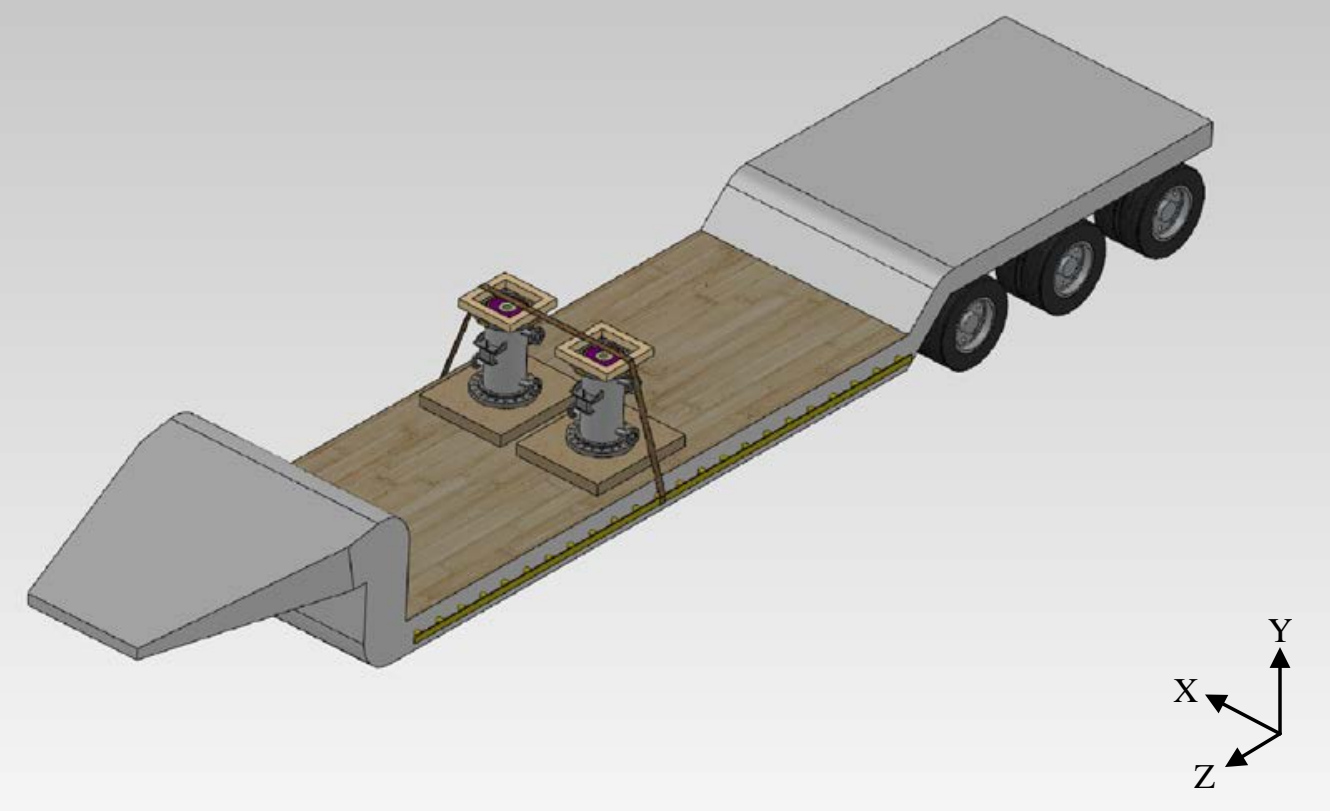

X: Lateral Y: Vertical Z: Forward/Aft

Figure 4.2. Example of the Tie-Down Configuration for Spool Pieces

\subsection{Tie-Down Calculations}

The calculations in this section apply to the tie-down configuration shown in Figure 4.2. Rubber mats are not shown in the figure but are required.

\subsubsection{Forces}

The total estimated weight of two spool pieces each supported by a typical pallet is

$$
\mathrm{W}_{\text {system }}:=2000 \cdot \mathrm{lbf}
$$

In accordance with the Federal Motor Carrier Safety Administration's Cargo Securement Rules (FMCSA 2011), the tie-down configuration shall restrain the load from a g-force of 0.8 in the forward direction, 0.5 in the aft/backward direction, 0.5 in the lateral direction, and 0.5 in the vertical direction.

The CRC Handbook of Chemistry and Physics (Lide 1991) reports friction factors ranging from 1 to 4 for rubber mats. A coefficient of friction of 0.4 is conservatively used. To ensure that a friction of at least this magnitude is always present a friction-enhancing load mat shall be placed under all pallets. This requirement is intended to restrict forward, aft, and lateral movement under the specified worst-case inertial loads. 
Coefficient of friction (Lide 1991):

$$
\mu:=0.4
$$

Forward, aft, lateral, and vertical g-force values:

$$
\begin{gathered}
\mathrm{g}_{\text {forward }}:=0.8 \\
\mathrm{~g}_{\mathrm{aft}}:=0.5 \\
\mathrm{~g}_{\text {lat }}:=\mathrm{g}_{\mathrm{aft}} \\
\mathrm{g}_{\mathrm{vert}}:=0.5
\end{gathered}
$$

\subsubsection{Strapping Setup}

For a configuration with two spool pieces each supported on a typical wooden pallet, one strap or chain shall be placed across the top flanges similar to the setup shown in Figures 4.2 and 4.3. Use of a frame made of $4 \times 4$ lumber is also suggested (shown across the top).

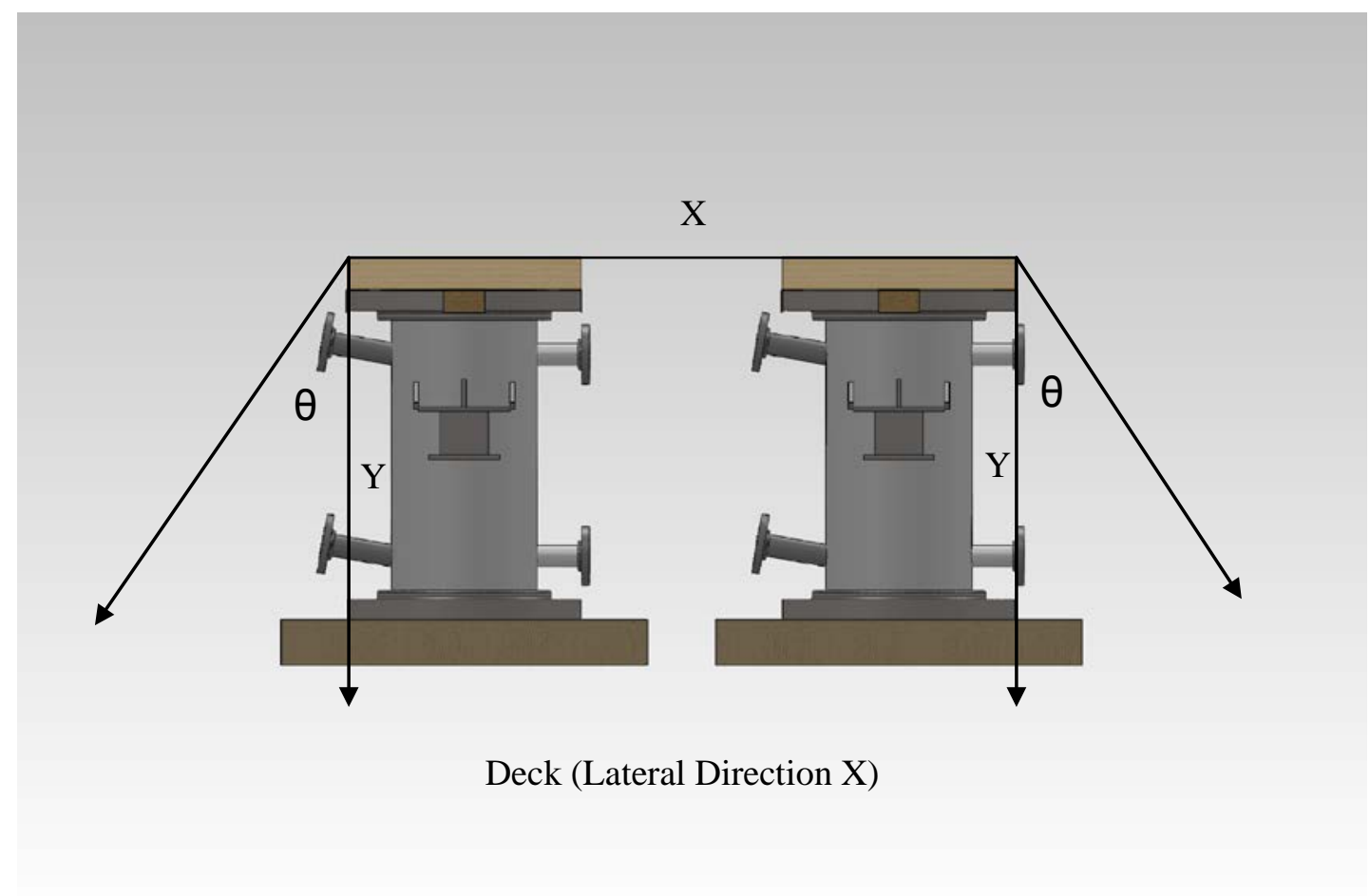

Figure 4.3. Angle Calculation Definition

Angle between strap and spool piece:

$$
\theta_{\text {strap }}:=70.4 \cdot \operatorname{deg}
$$




\subsubsection{Lateral Restraint Calculations}

In Figure 4.2, the lateral direction is also called the $\mathrm{X}$ direction. Lateral restraint is provided by using a single strap or chain across the top flanges of both spool pieces. The ends of the strap are then secured to the conveyance. To avoid damage to the strap, any edge that comes in contact with the strap should be padded. Alternatively, more than one strap may be used.

Load in the lateral direction(s):

$$
\mathrm{F}_{\text {lat }}:=\mathrm{W}_{\text {system }} \cdot \mathrm{g}_{\text {lat }}
$$

Solving for tension in the chain or strap:

$$
\begin{gathered}
\mathrm{T}_{\text {lateral }}:=\frac{\mathrm{F}_{\text {lat }}}{\sin \left(\theta_{\text {strap }}\right)} \\
\mathrm{T}_{\text {lateral }}=1.062 \times 10^{3} \mathrm{lbf}
\end{gathered}
$$

The working load limit of one strap in the lateral direction must be 1,250 lb or greater.

\subsubsection{Vertical Restraint Calculations}

In Figure 4.2, the vertical direction is also called the $\mathrm{Y}$ direction. Vertical restraint is provided by using a single strap or chain across the top flanges of both spool pieces. The ends of the strap are then secured to the conveyance. To avoid damage to the strap, any edge that comes in contact with the strap should be padded.

Load in the vertical direction:

$$
\mathrm{F}_{\text {vertical }}:=\mathrm{W}_{\text {system }} \cdot \mathrm{g}_{\mathrm{vert}}
$$

Solving for tension in the chain or strap:

$$
\begin{aligned}
& \mathrm{T}_{\text {vertical }}:=\frac{\left(\frac{\mathrm{F}_{\text {vertical }}}{2}\right)}{\cos \left(\theta_{\text {strap }}\right)} \\
& \mathrm{T}_{\text {vertical }}=1.491 \times 10^{3} \mathrm{lbf}
\end{aligned}
$$

The working load limit of one strap in the vertical direction must be 1,750 lb or greater. 


\subsubsection{Forward Restraint Calculations}

In case chocking is not used for forward and aft restraint, the preload of straps can be calculated by balancing forward inertial load with opposing friction force. Forward restraint calculations are as follows (Hibbeler 2004):

Load in the forward direction:

$$
\mathrm{F}_{\text {forward }}:=\mathrm{W}_{\text {system }} \cdot \mathrm{g}_{\text {forward }}
$$

Friction force:

$$
\mathrm{f}=\mu \cdot \mathrm{N}_{\text {normal }}
$$

Force balance:

$$
\mathrm{F}_{\text {forward }}-\mathrm{f}=0
$$

Solve for normal force:

$$
\begin{gathered}
\mathrm{g}_{\text {forward }} \cdot \mathrm{W}_{\text {system }}=\mu \cdot \mathrm{N}_{\text {normal }} \\
\mathrm{N}_{\text {normal }}:=2 \cdot \mathrm{W}_{\text {syster }} \\
\mathrm{N}_{\text {normal }}=\mathrm{W}_{\text {system }}+2 \cdot \mathrm{Y}_{\text {down }}
\end{gathered}
$$

Tension of Y component in one strap:

$$
\begin{gathered}
\mathrm{Y}_{\text {down }}:=\frac{\left(\mathrm{N}_{\text {normal }}-\mathrm{W}_{\text {system }}\right)}{2} \\
\mathrm{Y}_{\text {down }}=1 \times 10^{3} \mathrm{lbf}
\end{gathered}
$$

Minimum preload required per strap:

$$
\begin{gathered}
\mathrm{T}_{\text {preload }}:=\frac{\left(\mathrm{Y}_{\text {down }}\right)}{\cos \left(\theta_{\text {strap }}\right)} \\
\mathrm{T}_{\text {preload }}=2.981 \times 10^{3} \mathrm{lbf}
\end{gathered}
$$

To provide forward restraint, each strap or chain should be preloaded to at least 3,250 lb, requiring a strap working load limit of 4,000 lb or greater. 



\subsection{References}

InEnTec Website. InEnTec LLC, 2011. http://www.inentec.com/ Accessed in March 2011.

Federal Motor Carrier Safety Administration Cargo Securement Rules. http://www.fmcsa.dot.gov/rulesregulations/truck/vehicle/cs-policy.htm Accessed in March 2011.

Hibbeler, RC. 2004. Engineering Mechanics, Statics and Dynamics. Tenth Edition, Pearson Prentice Hall, Upper Saddle River, New Jersey.

Lide, DR (ed.). 1991. CRC Handbook of Chemistry and Physics. 72nd revised edition, CRC Press Inc., Boca Raton, Florida. 



\section{Appendix A}

Drawings and Figures 



\section{Appendix A - Drawings and Figures}

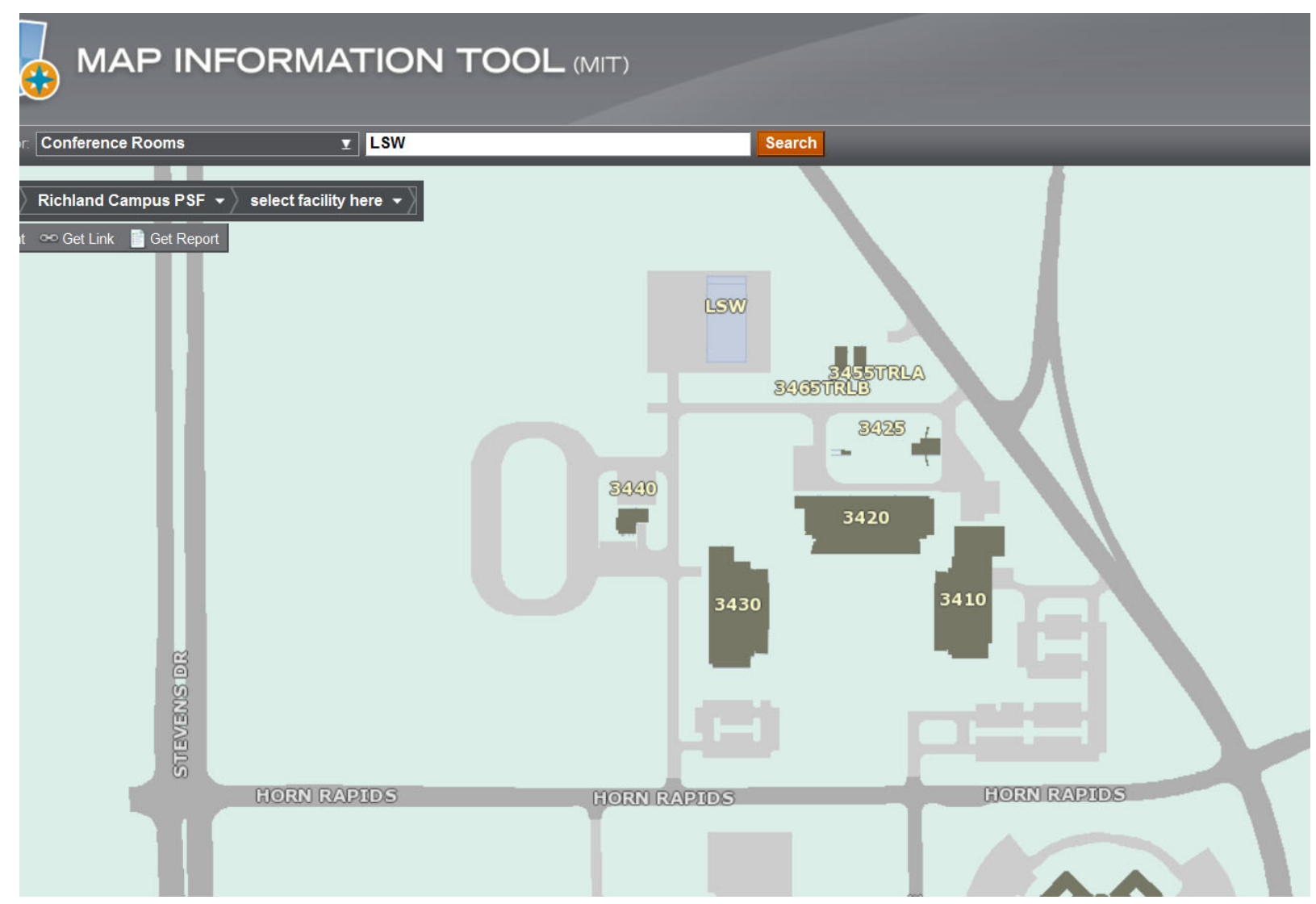

Figure A.1. Map of PNNL's North Campus Showing the Location of the LSW 


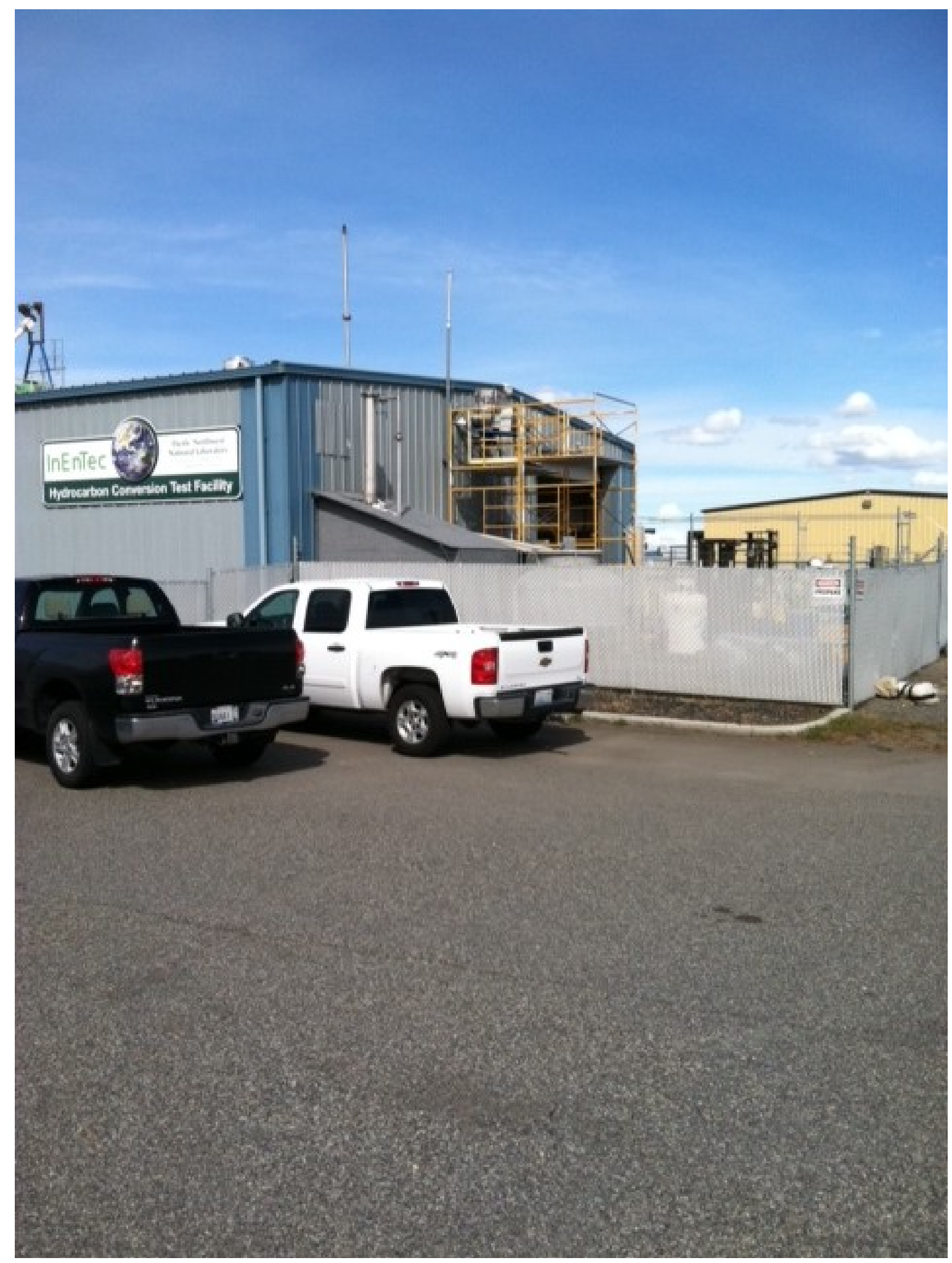

Figure A.2. InEnTec Facility 


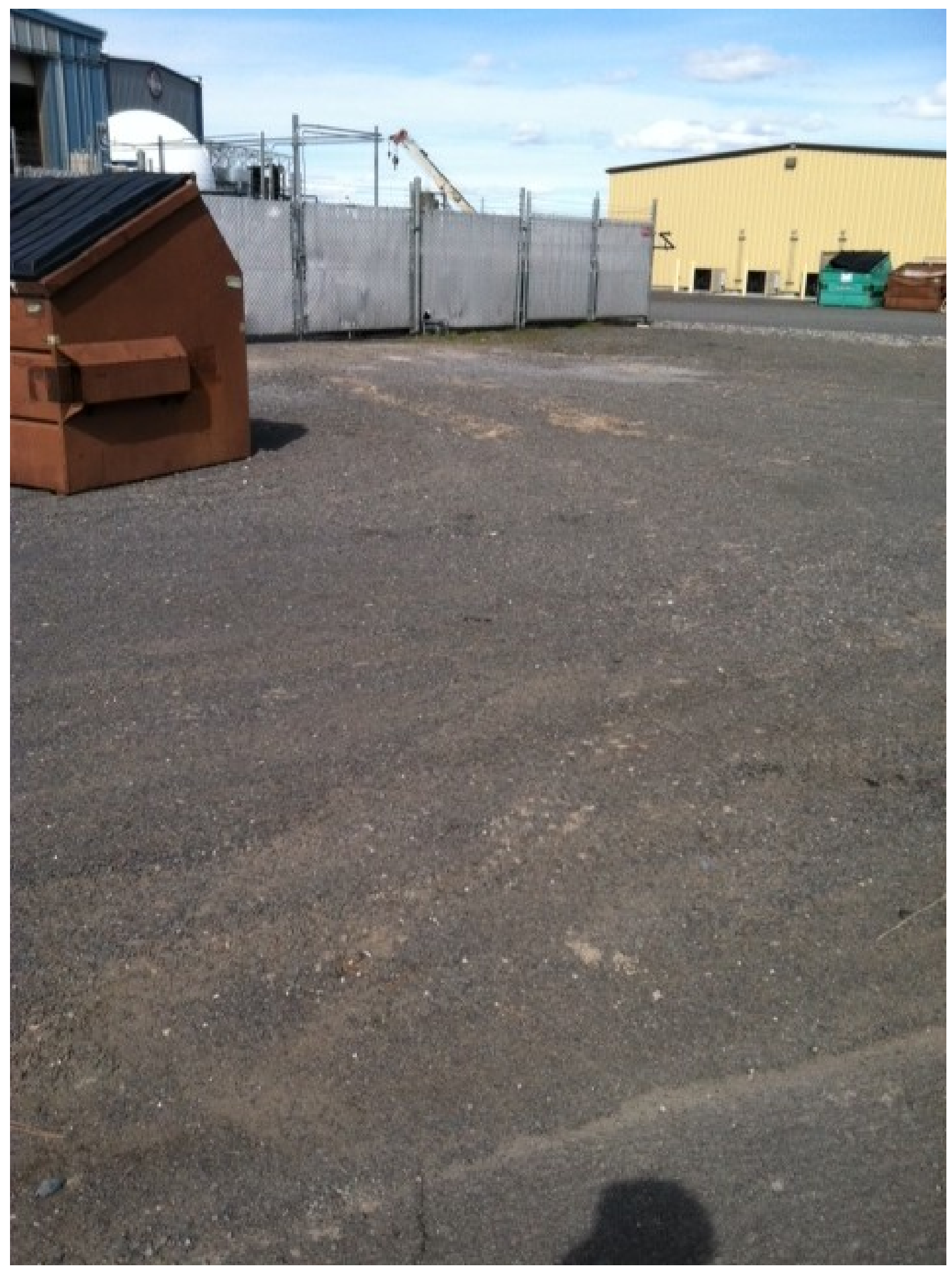

Figure A.3. InEnTec Laydown Yard 

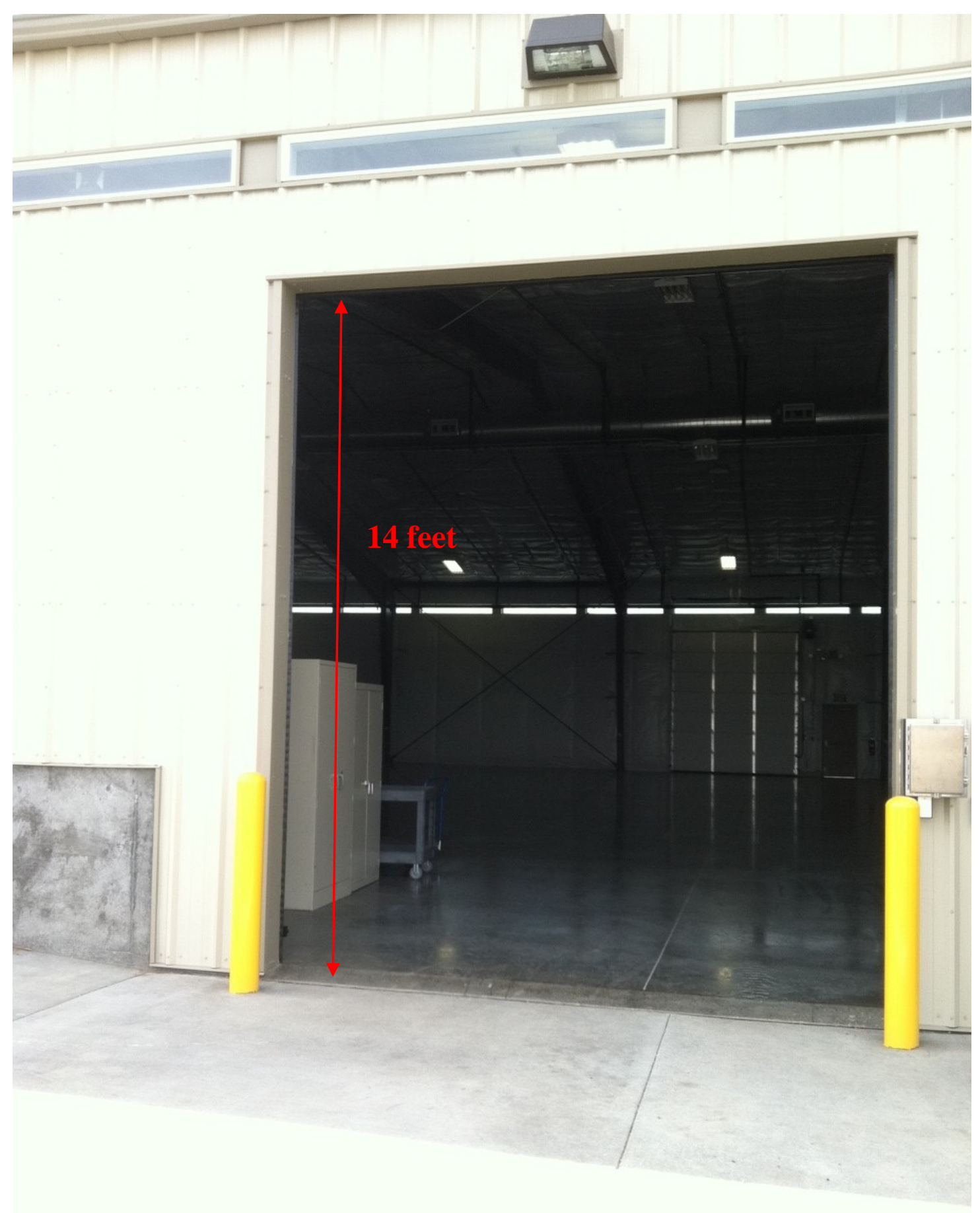

Figure A.4. LSW Entry Way. Maximum height is 14 feet. 


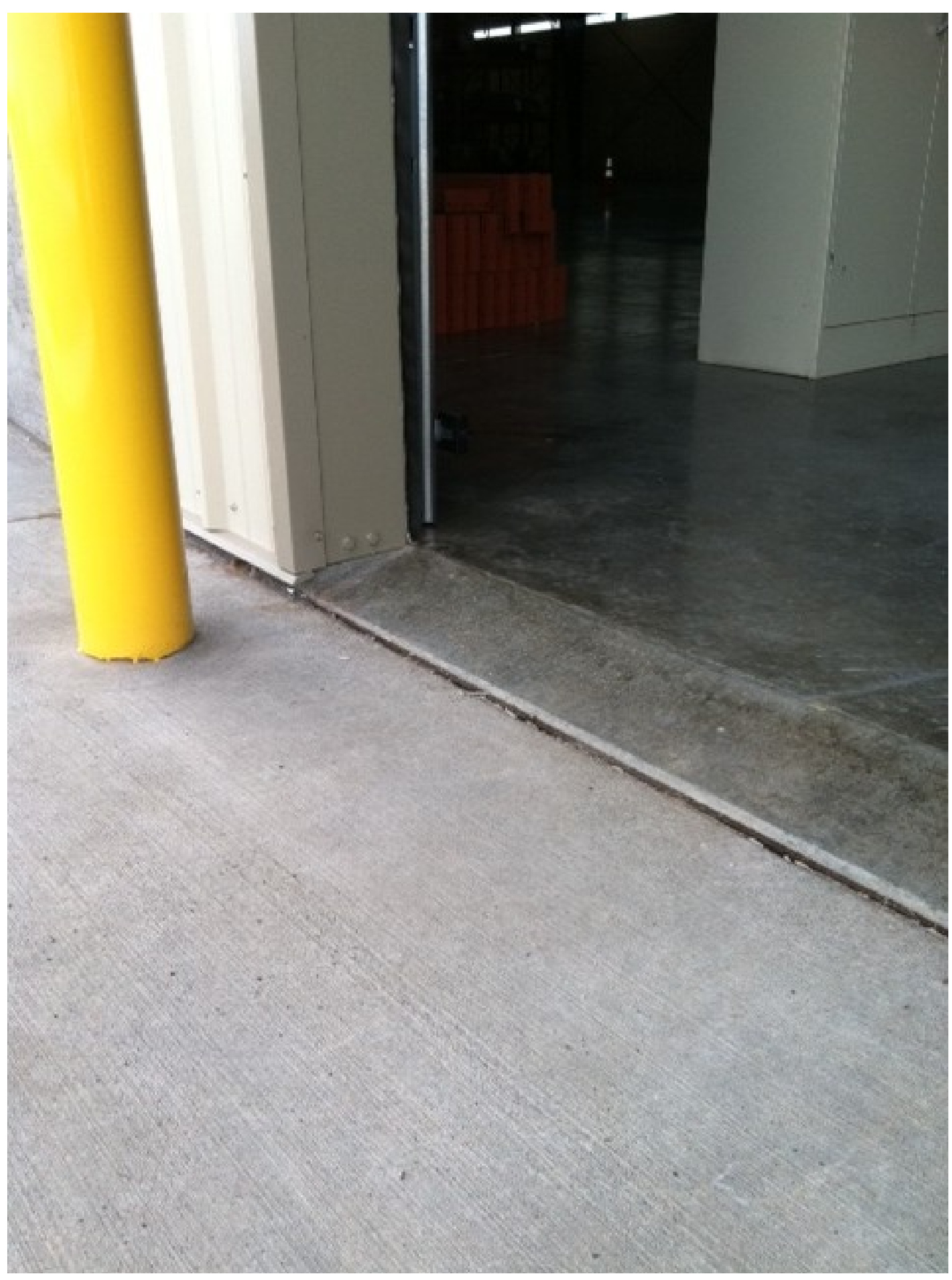

Figure A.5. LSW Entry Way "Step” 


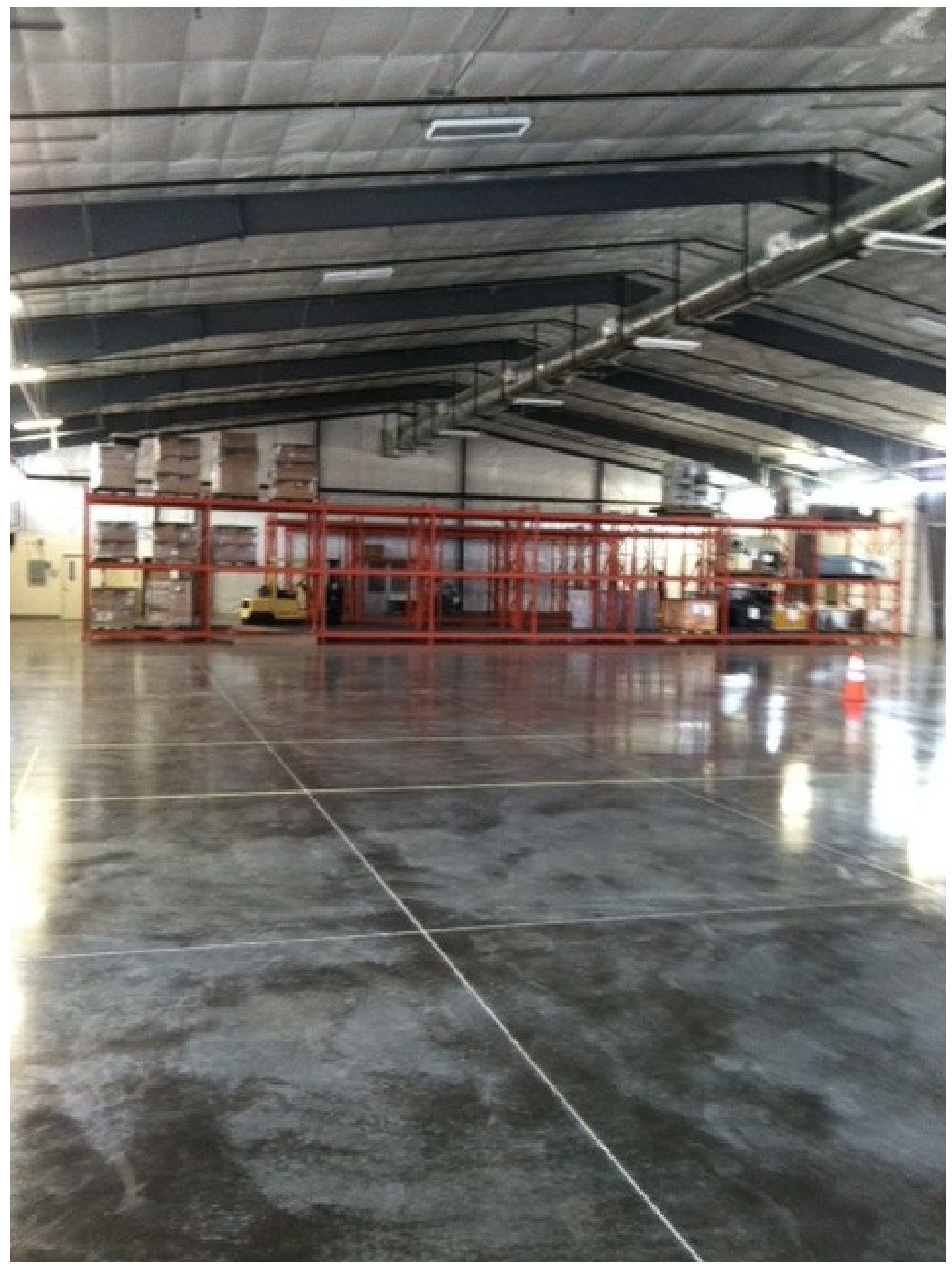

Figure A.1. Interior View of the LSW 

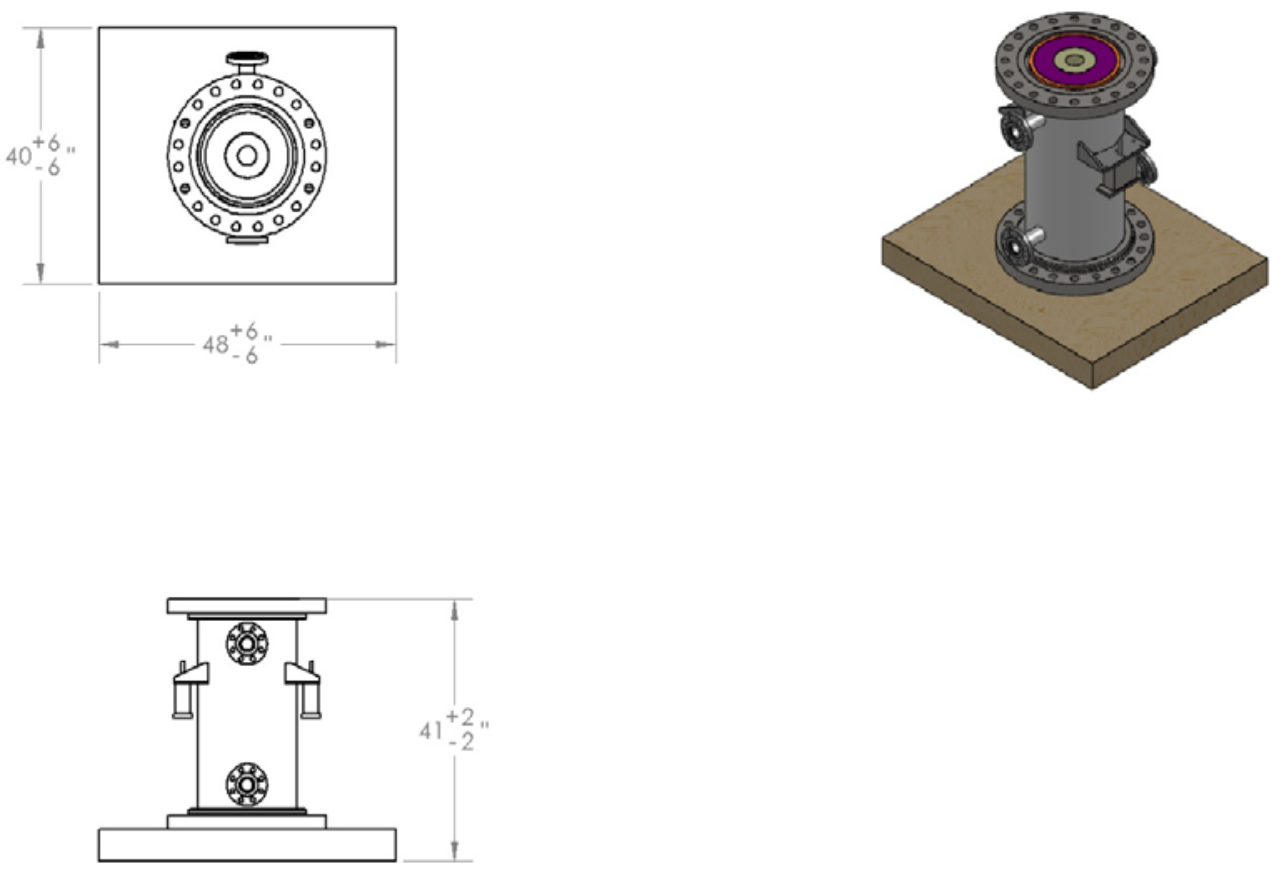

- TWO ASSEMBLIES WITH THESE APPROXIMATE DIMENSIONS

- SPOOL SHALL BE BANDED TO PALLET

Figure A.7. Height and Footprint Dimensions of Middle and Upper Spool Pieces (in inches) 

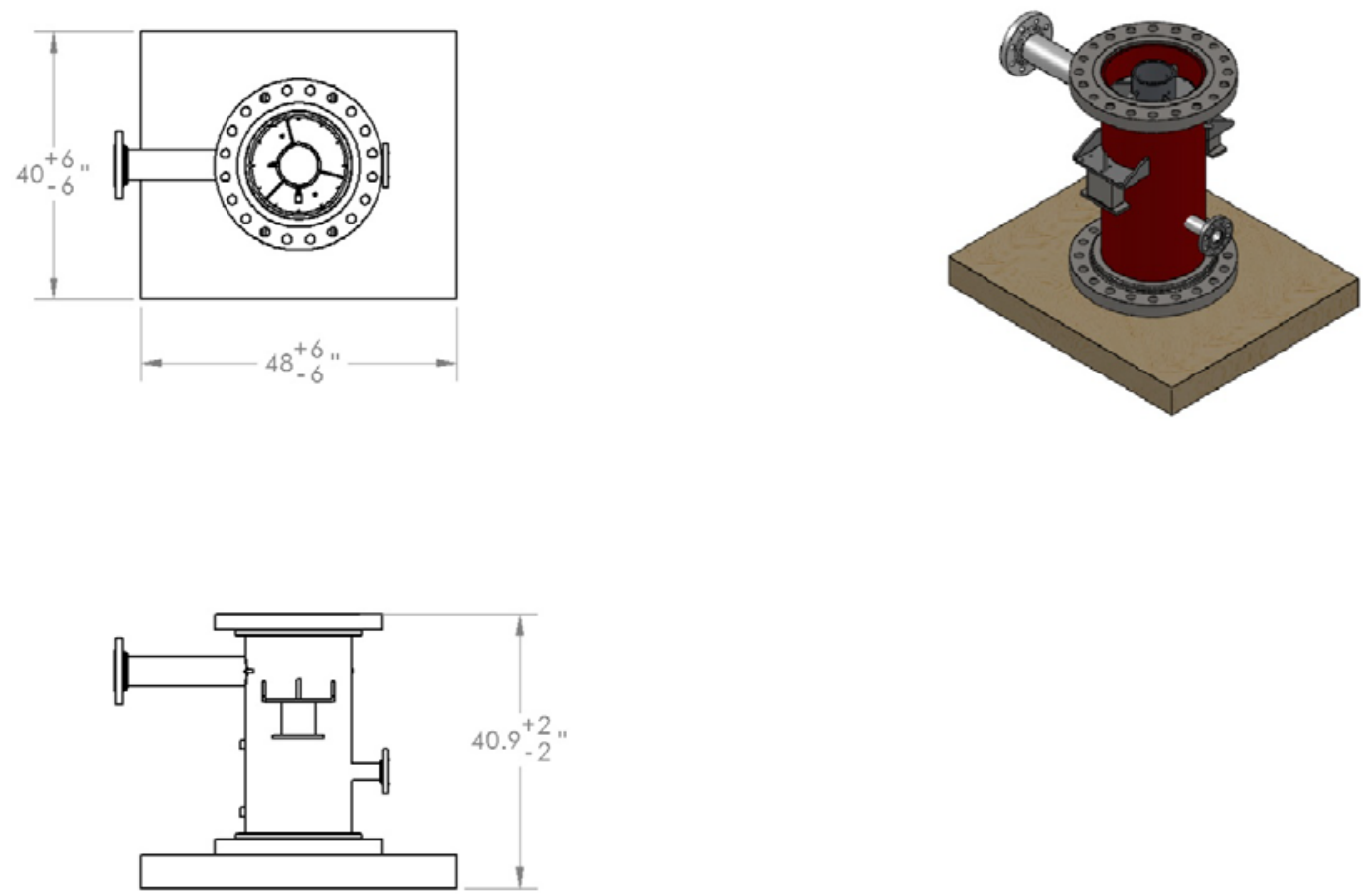

- SPOOl PIECE Shall Be Banded to Pallet

- tOTAL WeIGHT OF SPOOL 1000 LBS

Figure A.8. Height and Footprint Dimensions of Lower Spool Piece (in inches) 

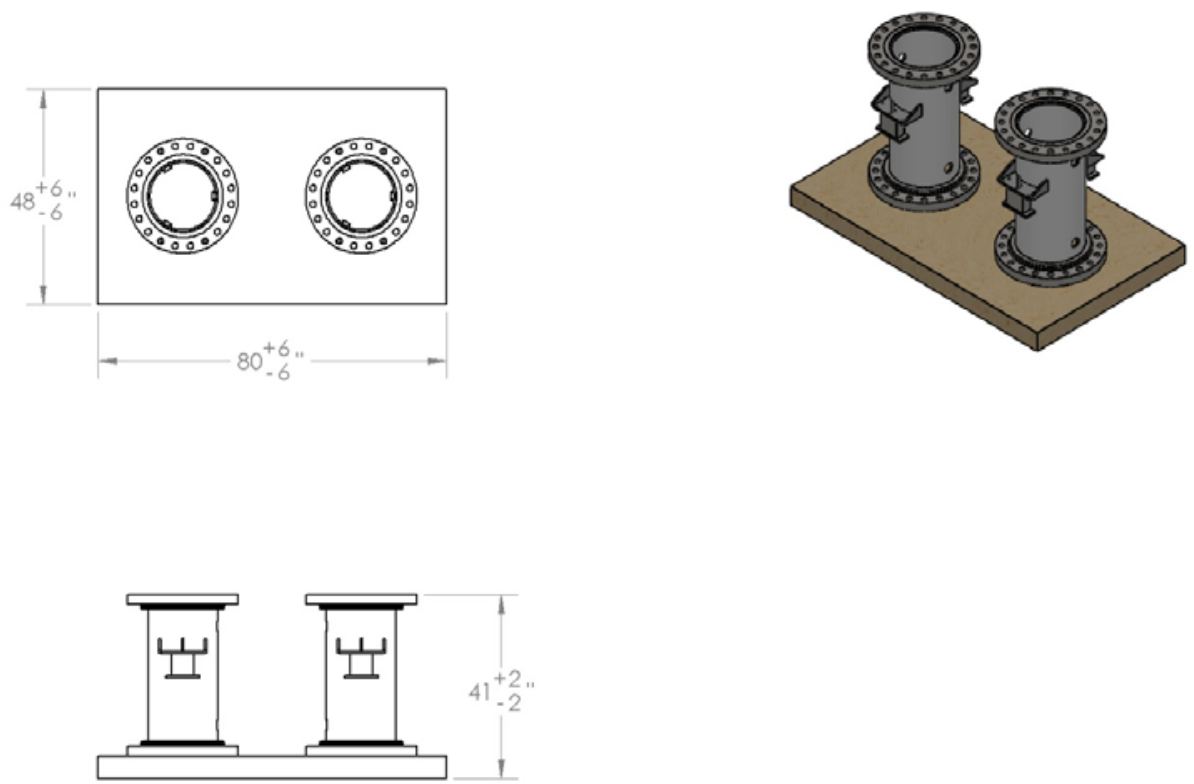

- Spool pieces are alReady banded onto pallet

Figure A.9. Height and Footprint Dimensions of Extra Spool Pieces (in inches) 


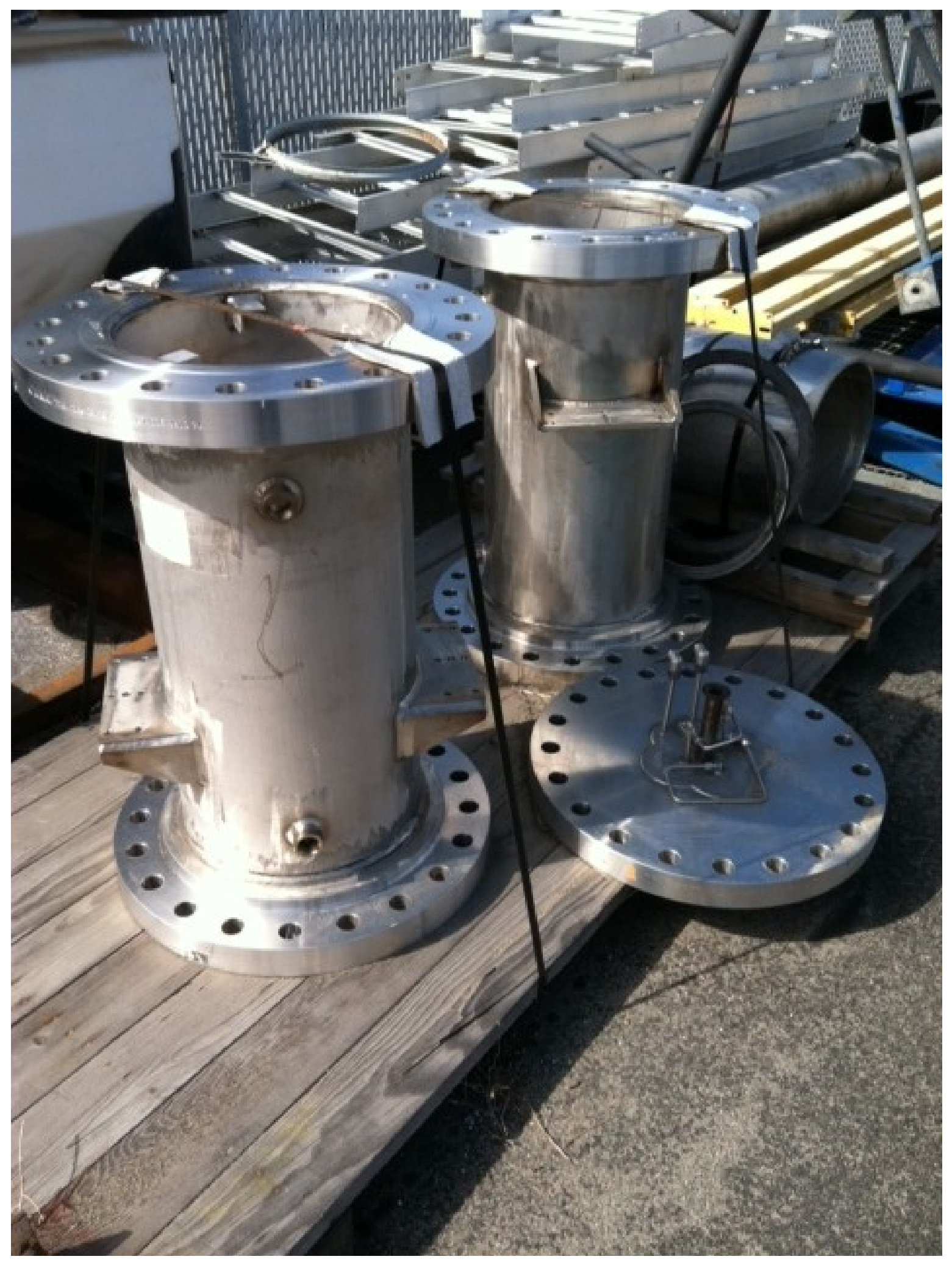

Figure A.10. Extra Spool Pieces Attached to Pallet at InEnTec 


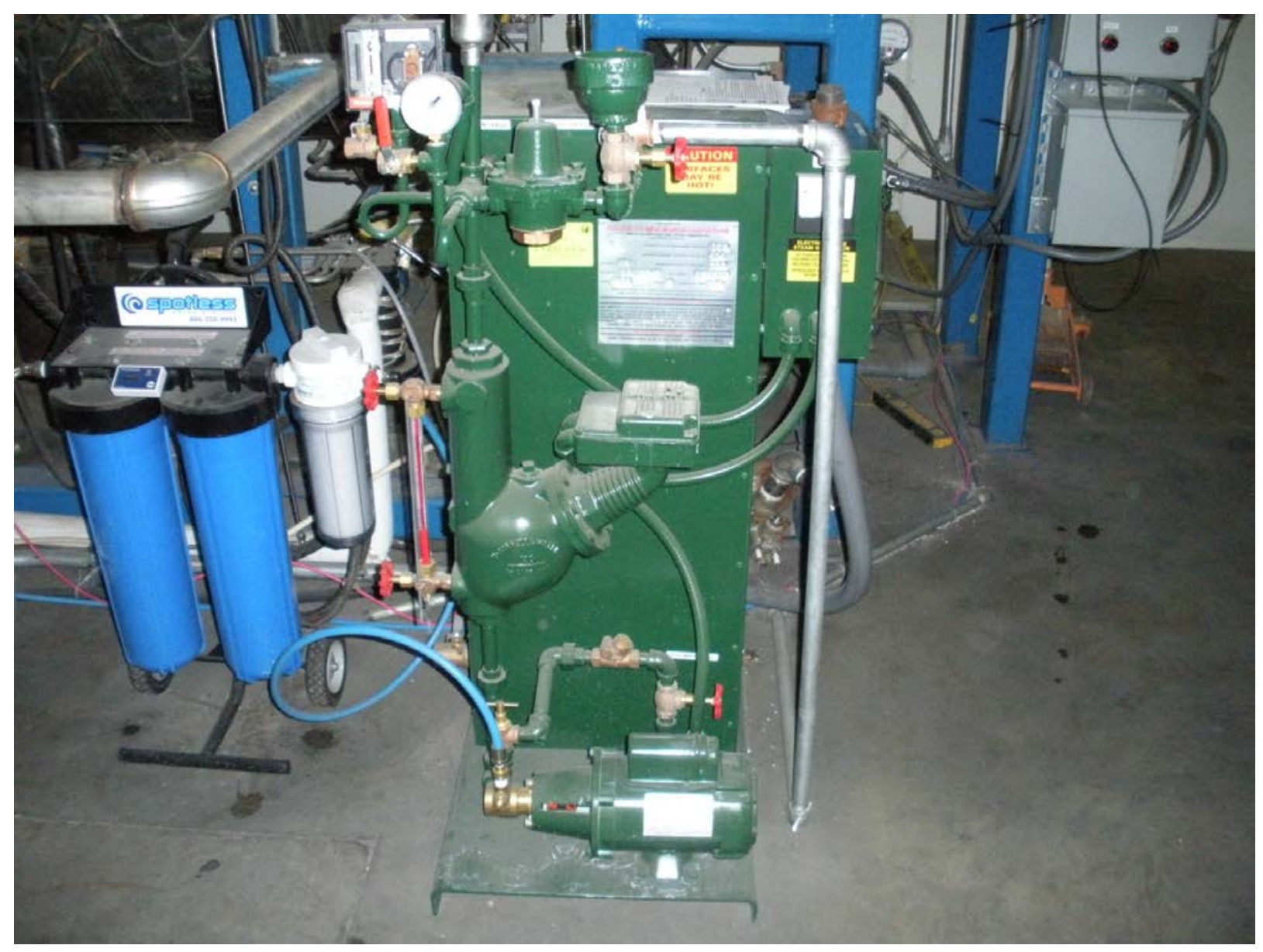

Figure A.11. Gasifier Boiler 



\section{Distribution}

No. of

Copies

3 Local Distribution

Pacific Northwest National Laboratory

Hanford Technical Library

D Reid

AD Guzman
No. of

Copies

Distr.1 




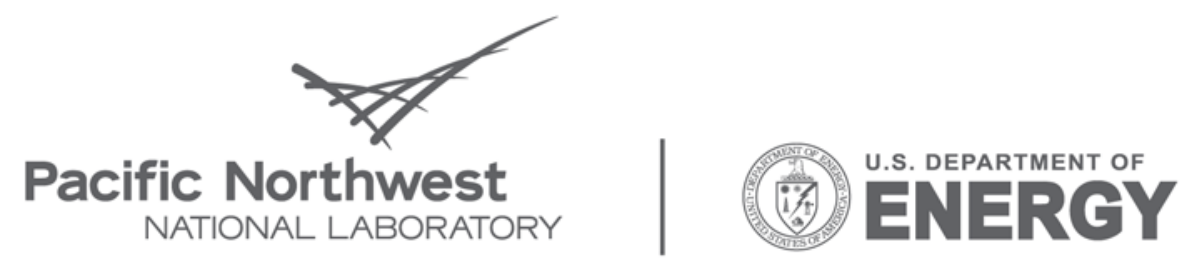

Proudly Operated by Battelle Since 1965

902 Battelle Boulevard

P.O. Box 999

Richland, WA 99352

1-888-375-PNNL (7665)

www.pnl.gov 